\title{
Motif Politik dalam Kelahiran dan Pembentukan Gerakan Arah Baru Indonesia (Garbi)
}

\section{Arfan Ashari Saputra ${ }^{1}$, Ridho Al-Hamdi ${ }^{2}$}

1,2 Magister Ilmu Pemerintahan, Universitas Muhammadiyah Yogyakarta

\begin{abstract}
Abstrak:
Tulisan ini mengkaji motif politik dalam kasus kelahiran dan pembentukan Gerakan Arah Baru Indonesia (Garbi). Kemunculannya dinilai oleh tiga motif politik: motif insentif material, insentif solidaritas, dan insentif idealisme. Sementara pembentukan diukur oleh struktur kesempatan politik, mobilisasi, dan framing. Secara metodologis, ini adalah penelitian kualitatif dengan menerapkan dua teknik pengumpulan data, yakni wawancara mendalam dan dokumenter. Temuan penulis menunjukkan bahwa di antara tiga motif, insentif solidaritas dapat dibuktikan sebagai faktor penentu yang mempengaruhi munculnya Garbi. Sementara itu, framing adalah struktur yang mendominasi satu dengan lainnya. Ini menunjukkan bahwa Garbi bukan hanya gerakan elit karena kekuatan solidaritas yang murni berasal dari pengikut Garbi di akar rumput. Dengan memanfaatkan strategi framing, formasi Garbi bisa mendominasi persepsi publik.
\end{abstract}

\section{Keywords:}

motif politik, gerakan sosial, Garbi, solidaritas, framing

\section{Pendahuluan}

ada era reformasi, partai politik cenderung mengalami konflik internal.
Konflik internal umumnya disebabkan oleh faktor pilihan oposisi dan
koalisi. Partai-partai politik yang terlibat dalam konflik internal, sebagian kecenderungan memunculkan perpecahan yang berujung pada lahirnya kepengurusan ganda dan sebagian lagi melahirkan partai-partai baru (Romli, 2018). Konflik umumnya dapat didefinisakan sebagai relasi psikologis yang tujuannya sangat erat berkaitan dengan sikap emosional yang bermusuhan maunpun nilai-nilai yang berbeda (Kartono, 2018: 246). Dalam era reformasi saat ini hampir keseluruhan partai politik di Indonesia merupakan "peranakan" lahirnya partai baru dari pecah kongsinya internal partai lama yang dalam dinamikanya mengalami perubahan karakteristik maupun perubahan pelembagaan. Aminuddin \& Ramadlan (2015), mengacu pada konflik politik Surbakti 
(1999: 153) membuat klasifikasi terbagu dalam dua tipe yakni konflik positif dan konflik negatif, konflik positif ialah yang eksistensinya tidak mengancam struktural maupun sistem politik dan dapat diselesaikan dengan jalan konstitusi. Sedangkan konflik negatif yaitu konflik yang dapat mengancam eksistensi suatu sistem politik melalui cara non konstitusional seperti revolusi dan kudeta. Konflik dalam partai politik di Indonesia membenarkan bahwa suatu alirian maupun ideologi terjadinya konflik disebabkan adanya unsur negatif pada pengembangan kekokohan partai (Huntington \& Simamora, 1983)

PKS (Partai Keadilan Sejahtera) sebagai partai politik islam yang berhasil meningkatkan perolehan suaranya dalam setiap kali pemilu di tengah tingginya gejala electoral volatility tentunya tidak terlepas dengan konflik internal yang terjadi didalamnya. Penempatan PKS sebagai partai islam kedua tersukses tentunya berdasarkan pada pencapaian PKS dalam setiap pemilu. Pencapaian elektoral PKS temtunya menjadi sebuah prestasi bagi sebuah partai islam (Muhtadi, 2013). Dalam perjalanan keberhasilan PKS mengalami momen-momen kritis sepanjang keikut sertaanya dalam pemilu. Persoalan tersebut tidak memberi dampak yang serius terhadap performa partai seperti halnya yang dialami oleh beberapa partai lainnya yang merasakan dampak negatif terhadap perolehan suaranya, PKS justru mengalami kecenderungan peningkatan perolehan suara di setiap pemilu (Rivai, 2016).

Keberhasilan tersebut tidak membuat PKS mampu menjaga kohesivitas dan soliditas dalam internal partai. Mulai dari perbedaan pandangan, perpecahan dukungan pencalonan dalam pemilu presiden, tidak terakomodasinya usulan di dalam partai, serta perbedaan pemberian dukungan terhadap calon pimpinan partai di dalam suksesi internal partai membuat internal partai PKS terdapat celah peluang pengembangan tipologi partai politik. Gunther \& Diamond (2003) menyebutkan tipologi partai politik saat ini masih terdapat peluang dan celah untuk memberikan varian partai baru, termasuk pada tipologi kepartaian yang sudah ada. Konflik internal pun semakin tercium sejak perbedaan pandangan pada pilpres 2004, munculnya dua kubu dalam internal PKS yakni faksi keadilan dan faksi sejahtera dengan perbedaan pandangan hidup kader atas sumber daya finansial, baik pandangan untuk menjadikan PKS sebagai partai yang terbuka bagi non-muslim dan mewajibkan seluruh caleg PKS menandatangani surat pengunduran diri bertanggal kosong (Budiatri et al., 2017). Secara sederhana, faksi dalam partai politik dapat didefinisikan sebagai pengelompokan orang di dalam partai yang berkompetisi untuk memperoleh keuntungan kekuasaan di dalam partai (Romli, 2018). Wacana partai poltik "terbuka" di PKS telah memunculkan tiga pandangan kader, salah satu konflik yang muncul dalam internal PKS bahwa terdapat tiga padangan kader yakni mendukung sebagai partai, netral, dan menolak partai PKS sebagai parpol yang terbuka (Munandar, 2011). Sekalipun demikian PKS masih sangat tertutup dalam seleksi kandidat dan kaderisasi politik. Permainan politik yang diinginkan yakni dengan 
merangkul pemilih dari berbagai kalangan agar mendapatkan dukungan politik demi menjaga oligarki dan relasi klientelistik partai (Tomsa, 2012).

Pada pertengahan tahun 2018, sebuah organisasi kemasyarakatan hadir sebagai sebuah gerakan kebangsaan yang diberi nama Garbi (gerakan arah baru Indonesia) dengan beberapa tokoh inisiatornya yang merupakan tokoh-tokoh vital sejak menjabat dalam kepengurusan partai PKS. Diantaranya ialah Anis Matta, Fahri Hamzah, dan Mahfudz Siddiq. Ketiga tokoh tersebut merupakan penggagas ide arah baru Indonesia sehingga gerakan arah baru Indonesia (Garbi) bisa dapat mendeklarasikan dirinya di berbagai kota maupun daerah yang ada di Indonesia. Melihat kondisi ini tentunya semakin memberikan sinyal kuat bahwa soliditas dan kohesivitas dalam internal PKS menjadi tidak kondusif ditambah dengan kader-kader PKS ramai-ramai mengundurkan diri dan bergabung dalam gerakan arah baru Indonesia. Kehadiran Garbi yang digagas oleh Anis Matta (Mantan Presiden PKS 2013-2015) merupakan ormas yang kuat dugaan berangkat akibat kekecewaan karena tidak mendapatkannya ruang dan perbedaan pandangan dalam internal PKS. Wahyudi (2011: 19) menyebutkan konflik setidaknya terjadi pada proses kondisi yang mendahuluinya. Permulaan konflik (antecendents of conflict) merupakan konndisi yang menyebabkan suatu peristiwa konflik. Kekecewaan (frustration) merupakan pertistiwa yang mengawali munculnya konflik. Kekecewaan biasanya gejalagejala yang tidak dapat dilihat dan tidak dapat diungkapkan secara terbuka oleh masingmasing kelompok maupun individu. Terry \& Smith (1990) menambahkan bahwa konflik umumnya terjadi kesalahpahaman antar invidu ataupun kelompok akibat krisis memperebutkan sumber daya maupun jabatan, menjadikan berkonfrontasi menjadi pusat perhatian dan dikelola menjadi kelompok baru.

Dalam buku perpecahan dan soliditas partai islam (Noor, 2015). PKS menjadi satu-satunya partai islam yang dapat menghindari perpecahan meskipun dalam sepuluh tahun pertama fregmentasi dan faksionalisme banyak dialami oleh partai politik utamanya partai kontemporer Indonesia. PKS dianggap berhasil mengelola perbedaan internal, perbedaan aspirasi, perbedaan pendapat sehingga berhasil mengonsolidasikan partai. Belakangan konfilk yang terus terjadi dalam internal PKS dengan adanya faksi keadilan dan faksi sejahtera ditambah dengan semakin sejumlah kader memutuskan mundur sebagai calon legislatif (caleg) pada pemilu 2019. Keluarnya tokoh-tokoh vital hingga membentuk forum diluar dari internal partai yaitu Forum Kader Peduli (FKP) yang kehadirannya tidak membuat soliditas partai menjadi terbelah. Berbeda dengan Garbi, setelah drama kasus pemecatan Fahri Hamzah diikuti dengan beberapa kader yang mendaftarkan diri sebagai calon legislatif juga mengundurkan diri dalam pencalonannya melalui PKS, menariknya Anis Matta juga memutuskan mundur dari PKS bersama dengan Mahfudz Siddiq dan Sita Sukanto. Kemudian kisruh mundurnya beberapa pejabat partai semakin memperkeruh internal partai yang disinyalir munculnya gerakan isu Osan (orang sana) dan Osin (orang sini) yang diklaim sebagai Osan 
merupakan lahirnya Garbi (Gerakan Arah Baru Indonesia) (Nurdin, Saputra, \& Prayitno, 2019).

Tabel 1. Perbedaan antara FKP dan Garbi

\begin{tabular}{|c|c|c|}
\hline Item & FKP & Garbi \\
\hline Timeline & Tahun 2007-2015 & $\begin{array}{l}\text { Sejak 2002, massif tahun 2015- } \\
2018 \text { dan berlanjut }\end{array}$ \\
\hline Asal Mula & $\begin{array}{l}\text { Emosional, tausiyah, dan } \\
\text { ketidakpuasan }\end{array}$ & $\begin{array}{l}\text { Ambisi jabatan dan operasi } \\
\text { intelijen dari luar }\end{array}$ \\
\hline Tujuan & $\begin{array}{l}\text { Meluruskan sikap sebagian } \\
\text { qiyadah }\end{array}$ & $\begin{array}{l}\text { Mengambil alih dan mnegkudeta } \\
\text { majelis syuro dan partai }\end{array}$ \\
\hline Danger Level & $\begin{array}{l}\text { Tidak terlalu berbahaya (yellow } \\
\text { alert) }\end{array}$ & $\begin{array}{l}\text { Sangat berbahaya (extremely red } \\
\text { alert) }\end{array}$ \\
\hline Posisi & Di luar jamaah PKS & Di dalam jamaah \\
\hline Sikap & $\begin{array}{l}\text { Jantan, terus terang, dan } \\
\text { bersikap jelas }\end{array}$ & Ambigu dan taqiyah \\
\hline Organisasi & Tidak terstruktur dan terencana & $\begin{array}{l}\text { Tandzim, terstruktur, terencana, } \\
\text { dan bertahap }\end{array}$ \\
\hline Tandzim 'Alami & $\begin{array}{l}\text { Tidak ada cantolan } \\
\text { international }\end{array}$ & Ada cantolan international \\
\hline Figur & Tidak punya figure sentral & Ada figure sentral \\
\hline Masyayikh & $\begin{array}{l}\text { SP, DRS, M, MIF, MTZ, H, } \\
\text { MIT, HN }\end{array}$ & $\begin{array}{l}\text { (9S: AM, AZ, AFY, MAR, JJ, } \\
\text { TW, AF, AR, FH), RAI, TZU, } \\
\text { NB, GAF, JI, AA, PM, NM, RD, } \\
\text { ASH, MMI, TN, DA, MIS, MG, } \\
\text { BH, RH, TA, HY, AB, MSB, } \\
\text { RM, AP, AR, RA, AS, JJ, EK, } \\
\text { MS, NJ, N, ABA, YK, HS, AZ, } \\
\text { FP, }\end{array}$ \\
\hline Movement & Gerakan tidak massif & $\begin{array}{l}\text { Gerakannya semua massif } \\
\text { disemua lini }\end{array}$ \\
\hline Waktu & Temporer & Kontinyu \\
\hline Agresi & Tidak terlalu agresif & $\begin{array}{l}\text { Sangat aktif dan agresif merekrut } \\
\text { internal }\end{array}$ \\
\hline Finansial & $\begin{array}{l}\text { Sedikit memiliki potensi } \\
\text { finansial }\end{array}$ & $\begin{array}{l}\text { Memiliki finansial yang sangat } \\
\text { besar }\end{array}$ \\
\hline Cara merekrut & $\begin{array}{l}\text { Via usar, dakwah fardiyah, dan } \\
\text { blogspot }\end{array}$ & $\begin{array}{l}\text { Dauroh, usar, dakwah fardiyyah, } \\
\text { media sosial, ngopi bareng FH, } \\
\text { orasi ABI }\end{array}$ \\
\hline Institusi & $\begin{array}{l}\text { Lembaga dakwah kemuliaan } \\
\text { islam }\end{array}$ & $\begin{array}{l}\text { TFI, GEN AMPM, KAMMI, } \\
\text { KAKAMMI, AL-MANAR, IA } \\
\text { LIPIA, piyungan, mantan } \\
\text { relawan digital, cyber }\end{array}$ \\
\hline Media Sosial & $\begin{array}{l}\text { Kurang aktif menggunakan } \\
\text { media sosial }\end{array}$ & $\begin{array}{l}\text { Aktif dan massif dalam } \\
\text { menggunakan media sosial }\end{array}$ \\
\hline
\end{tabular}




\begin{tabular}{|c|c|c|}
\hline Narasi & $\begin{array}{l}\text { Kembali ke Asholah, tidak } \\
\text { main di wilayah abu-abu dalam } \\
\text { funding dan politik, serta } \\
\text { menghindari gaya hidup borjuis }\end{array}$ & $\begin{array}{l}\text { Ikhwan gagal, pembaharuan } \\
\text { manhaj, tafsir baru arkan, } \\
\text { erdogan, qiyadah tidak layak, } \\
\text { berkah tidak cukup, sikap kritis, } \\
\text { ada operasi intelijen, AMPM, } \\
\text { ABI, lompatan }\end{array}$ \\
\hline Pendukung & $\begin{array}{l}\text { Hanya sedikit dan kader inti } \\
\text { yang terlihat (ratusan orang) }\end{array}$ & $\begin{array}{l}\text { Banyak melibatkan na, aa, kader } \\
\text { inti dan kader pendukung. Klaim } \\
10.000 \text { dari } 500.000\end{array}$ \\
\hline Ending & Bubar dan kembali ke partai & Sedikit yang kembali ke partai \\
\hline Rekomendasi & $\begin{array}{l}\text { Mendekati, silaturahmi dan } \\
\text { mengajak kembali }\end{array}$ & $\begin{array}{l}\text { Pemebersihan Majelis Syuro, } \\
\text { Nuqoba, struktur, caleg dan } \\
\text { imunisasi kader. }\end{array}$ \\
\hline
\end{tabular}

Sumber: Dokumen Mewaspadai Gerakan Mengkudeta PKS

Ditengah ketegangan konflik yang terjadi dalam internal PKS, munculnya dokumen "Mewaspadai Gerakan Mengkudeta PKS" tidak lama menjelang pemilu 2019, dimana isi dokumen tersebut menarasikan istilah-istilah, latar belakang, hingga latar belakang, sumber dana, dan langkah-langkah antisipasi. Hasil analisis dari dokumen tersebut dibuat oleh seseorang yang mempunyai kemampuan intelijen dan strategi serta memiliki akses kepentingan dalam internal partai PKS. Beberapa pengurus PKS tidak mengetahui asal usul dokumen tersebut. Termasuk Anis Matta dan Mahfud Siddiq sebagai penggagas Garbi menyatakan bahwa dokumen tersebut adalah hoax (Akmar, 2019).

FKP sebagai forum kader peduli memposisikan dirinya diluar jamaah PKS, secara organisasi tidak terstruktur dan tidak terencana sehingga membuat pergerakannya tidak massif, Namun eksistensi FKP tidak sampai membuat soliditas partai menjadi terbelah, hingga hanya dianggap sebagai otokritik dari bagian partai politik. Kabar terakhir, tokoh-tokoh FKP justru kembali mendukung PKS di periodesasi kepemimpinan Sohibul Iman. Sedangkan Garbi yang sudah mulai massif pada 2015 hingga berlajut di tahun 2018 membentuk berbagai chapter di beberapa daerah dengan memiliki figur sentral. Selain itu Garbi hadir sebagai gerakan yang terstruktur, terencana dan bertahap. Sehingga agresi Garbi dianggap sangat aktif dalam merekrut khususnya dalam internal. Konflik yang terus terjadi dalam internal PKS mengakibatkan sejumlah pejabat PKS terlibat dalam pembentukan gagasan Arah Baru Indonesia (ABI) diantaranya Anis Matta, Mahfudz Siddiq, Fahri Hamzah, Sukamta, dan Jazuli Juwaini. Dalam perjalanannya Arah Baru Indonesia dimusuhi para piminan PKS era Shohibul Iman. Gagasan tersebut dituding sebagai gerakan mengkudeta PKS, sehingga tidak sedikit pengurus PKS yang dicopot akibat mengikut diskusi ABI. Setelah diskusi dan kajian yang panjang berlanjut dengan dibentuknya sebuah gerakan yang sampai saat ini di deklarasikan diberbagai kota. 


\section{Kelahiran dan Pembentukan Garbi sebagai Lokus Kajian}

Walgito (2010) memaknai motif sebagai kekuatan maupun dorongan yang ada dalam diri seseorang untuk mencapai segala bentuk tujuan yang ingin dicapainya. Pembagian motif politk menjadi tiga aspek yakni motif insentif material, motif insentif solidaritas, dan motif insentif idealisme. Seseorang yang berpatisipasi politik untuk memperoleh kedudukan yang lebih tinggi, mendapatakan kekuasaan, dan mendapatkan imbalan yang setimpal digolongkan sebagai motif insentif material. Kemudian keinginan seseorang untuk mendapatkan jaringan baru dengan menyatukan perasaan emosional serta moral yang terbentuk pada hubungan antar individu atau kelompok digolongkan sebagai motif insentif solidaritas. Sedangkan keinginan seseorang dalam memperjuangkan sesuatu yang bersifat ideal dan lebih mengutamakan kepentingan rakyat disbanding kepentingan individu digolongkan sebagai motif insentif idealism (Beck \& J.Sorauf, 1992: 115-126).

Lebih Lanjut Beck \& J.Sorauf (1992) menjelasakan bahwa motif untuk mencapai kekuasaan bisa timbul karena adanya sebuah kekecewaan sehingga ingin mendapatkan kedudukan yang lebih tinggi. Beberapa partai politik yang mengalami konflik internal maupun faksionalisasi cenderung dihadapkan pada sebuah kelompok yang kecewa baik ketidak sepahaman maupun adanya dualisme dalam internal partai. Sebagai partai yang memiliki profesionalisme yang tinggi tentunya PKS dapat menghindari konflik internal yang terjadi didalamnya sehingga soliditas partai dapat terjaga. Garbi dianggap sebagai ormas yang beirisi tokoh-tokoh pengikut Anis Matta dan berseberangan dengan kelompok Sohibul Iman. Dengan demikian dapat dipahami bahwa teori Beck \& J.Sorauf (1992) mengaitkan motif politik lahirmya gerakan arah baru Indonesia yang penyebarannya bersifat botton up.

Kemudian Situmorang (2007) membagi tiga gerakan sosial menjadi tiga aspek yakni sturuktur kesempatan politik, struktur mobilisasi, dan pembingkaian aksi. Dari struktrur kesempatan politik utamanya dipengaruhi melalui perubahan sturuktur politik sehingga adanya kesempatan dalam memanfaatkan momentum tersebut. Struktur mobilisasi menjadikan gerakan sosial melebur dalam aksi kolektif, upaya dalam memobilisasi baik formal maupun infomal. Hal tersebut dilakukan dalam pembingkaian aksi, melakukan penyebaran pandangan darinya kepada orang banyak untuk mendapatkan simpatisan. (Situmorang, 2007).

Sebuah gerakan sosial muncul dalam kondisi yang memungkinkan adanya sebuah kekecewaan yang bermetamorfosis menjadi mobilisasi, yang dari ketiga aspek gerakan sosial tersebut sebagai peran yang sangat penting dalam menentukan aksi-aksi kolektif baik dalam perubahan signifikan yang terjadi dalam struktur politik, juga biasanya berhubungan pergeseran-persegaran yang terjadi didalamnya (Hasan, 2006)). Beranjak dari permasalahan diatas, maka penelitian ini bertujuan mendekripsikan motif politik kelahiran gerakan arah baru Indonesia (Garbi) melalui pendekatan tiga motif politik yakni motif insentif material, motif insentif solidaritas dan motif insentif idealisme. Kemudian mendiskripsikan pembentukan Garbi melalui pendekatan gerakan sosial yaitu struktur 
kesempatan politik, struktur mobilisasi, dan pembingkaian aksi. Dalam upaya menjelasakan Garbi sebagai organsiasi kemasyarakatan yang lahir ditengah hangat konflik internal PKS dan momentum menjelang pemilu 2019.

Perkembangan ilmu politik khususnya kajian partai politik yang mengalami konflik internal dari berujung melahirkan partai baru bukan merupakan hal yang baru. Namun perbedaan penelitian ini dengan penelitian yang ada sebelumnya adalah dibandingkan dengan partai politik khususnya partai islam lainnya PKS adalah partai partai yang mampu menjaga soliditas partainya sehingga tidak menimbulkan perpecahan sejak sepuluh tahun terakhir terbentuknya partai ini. Namun menjelang pesta demokrasi pada pemilu 2019 justru gerakan arah baru Indonesia (Garbi) yang digagas mantan president PKS Anis Matta justru menawarkan ide kebangsaan yang baru, dengan perpaduan ide yang lebih terbuka. Kehadiran Garbi sebagai organisasi masyarakat tentunya banyak menimbulkan motif politik terkait pembentukannya diberbagai kota akibat banyaknya kader PKS yang terpaksa dipecat dan mengundurkan diri dan bergabung bersama Garbi. ditambah hadirnya Garbi kuat dugaan akan menjadi kendaraan politik Anis Matta dalam menatap pasar politik Indonesia.

Penelitian ini menggunakan metode penelitian kualitatif dengan berusaha mencari makna suatu fenomena yang berasal dari pandangan-pandangan para partisipan (culture sharing) serta mengidentifikasi suatu kelompok, kemudian meneliti bagaimana kelompok tersebut mengembangkan pola-pola dengan mengobservasi perilaku aktor dan para partisipan yang secara langsung terlibat dala aktivitas tersebut. Tipe penelitian yang digunakan adalah tipe penelitian deskriptif dengan lebih kepada pendekatan kualitatif. Pendekatan tersebut diharapkan akan menghasilakan data deskriptif berupa lisan dan tulisan dari aktor yang diamati.

Sumber data dalam penelitian ini meliputi data primer dan data sekunder. Data primer yaitu semua informasi mengenai kemunculan gerakan arah baru Indonesia, baik yang diperoleh secara langsung dari wawancara (indept interview) yang dijadikan obyek penelitian. Sedangkan data sekunder diperoleh melalui semua informasi mengenai kemunculan Garbi yang diperoleh secara tidak langsung tetapi melalui dokumendokumen yang mencatat keadaan konsep penelitian ataupun yang terkait dengannya sebagai alat pendukung analisis penelitian.

\section{Motif Insentif Material}

Motif Insentif Material dikenal sebagai imbalan atas upaya yang telah dikeluarkan dalam mencapai tujuan orgnaisasi dan untuk mencapai tujuan individu. Namun, pemberian insentif akan memicu motiviasi kerja seseorang agar menjadi lebih baik. Artinya insentif tidak hanya bermanfaat bagi individu, namun juga dapat dapat menguntungkan dalam organisasi untuk mencapai kekuasaannya. Dinamika muncul pada tahun 2015, Anis Matta tidak lagi menjadi presiden PKS. Shahibul Iman terpilih untuk menggatikan posisi Anis Matta. Sebelum Anis Matta diganti, ia menggagas sebuah ide kebangsaan yang diberi nama ABI (Arah Baru Indonesia), sebuah gagasan yang 
berisikan pendapat Anis Matta tentang Indonesia yang harus melakukan lompatan untuk menjadi negara besar, dengan masuk ke dalam lima besar kekuatan dunia.

Kelahiran Garbi dianggap sebagai bentuk kekecewaan terhadap internal PKS karena tidak mendapatnya ruang mengembangkan ide dan gagasan utamanya ide kebangsaan. Setidaknya ada pandangan umum yang muncul dalam tubuh PKS, yakni yang menolak adanya gerakan politik dalam partai politik, utamanya penolakan muncul langsung pada pengurus pusat PKS yang tidak menginkan kadernya mengikuti Garbi. Hasilnya beberapa kader yang keluar dari PKS lalu bergabung dengan Garbi. Sejak dideklarasikannya Garbi beberapa keder eks PKS banyak mendapatkan tempat yang strategis dalam pimpinan Garbi di berbagai chapter, baik menjadi dewan pembina hingga menjadi ketua umum dimasing-masing chapter yang tersebar hampir di seluruh Indoenesia.

Sebut saja beberapa contoh yang menarik untuk didiskusikan, seperti Rycko Menoza, Bupati Lampung Selatan (2010-2015) dan Handitya Narapati, Wakil Bupati Pringsewu (201-2016) adalah putra dari Gubernur Lampung Sjachroedin ZP (20042014); Ivan SJ Sarundajang, Wakil Bupati Minahasa (2013-2018) adalah putra Gubernur Sulawesi Utara Sinyo Harry Sarundajang (2010-2015); Syamsul Lutfi, Wakil Bupati Lombok Timur (2008-2013) adalah kakak dari Gubernur Nusa Tenggara Barat, Muhammad Zainul Majdi (2008-2018).

Tabel 2. Tokoh PKS yang bergabung di Garbi

\begin{tabular}{|c|c|c|c|}
\hline No & Nama & Jabatan di Garbi & Pengalaman di PKS \\
\hline 1. & M. Anis Matta & Penggagas \& Inisiator Garbi & $\begin{array}{l}\text { Ketua Umum PKS periode } \\
\text { 2013-2015 }\end{array}$ \\
\hline 2. & Fahri Hamzah & Penggagas \& Inisiator Garbi & $\begin{array}{l}\text { Wakil ketua DPR RI 2014- } \\
2019 \text { Fraksi PKS }\end{array}$ \\
\hline 3. & Mahfudz Siddiq & Penggagas \& Inisiator Garbi & $\begin{array}{l}\text { Anggota DPR RI 2014-2019 } \\
\text { Fraksi PKS }\end{array}$ \\
\hline 2. & Muh. Taslim Tamang & Ketua Harian Garbi Sulsel & Sekertaris DPW PKS Sulsel \\
\hline 3. & Febri A. Ibrahim & $\begin{array}{l}\text { Ketua Umum Garbi DKI } \\
\text { Jakarta }\end{array}$ & $\begin{array}{l}\text { Ketua bidang Ekuintel DPW } \\
\text { PKS DKI Jakarta }\end{array}$ \\
\hline 4. & Zuhrif Hudaya & $\begin{array}{l}\text { Ketua Umum Garbi DI } \\
\text { Yogyakarta }\end{array}$ & $\begin{array}{l}\text { Pengurus DPW PKS } \\
\text { DI. Yogyakarta }\end{array}$ \\
\hline 5. & Irwan S.T & $\begin{array}{l}\text { Sekertaris Umum Garbi } \\
\text { Sulsel }\end{array}$ & $\begin{array}{l}\text { Ketua Bidang Polhukam } \\
\text { DPW PKS Sulsel }\end{array}$ \\
\hline 6. & Mudzakkir Ali Djamil & $\begin{array}{l}\text { Bendahara Umum Garbi } \\
\text { Sulsel }\end{array}$ & $\begin{array}{l}\text { Ketua Fraksi PKS DPRD } \\
\text { Makassar }\end{array}$ \\
\hline 7. & Syamsari Kitta & $\begin{array}{l}\text { Ketua Umum Garbi } \\
\text { Sulawesi Selatan }\end{array}$ & $\begin{array}{l}\text { Bupati Takalar melalui partai } \\
\text { PKS }\end{array}$ \\
\hline 8. & Hasan Hamido & Ketua Garbi kota Makassar & $\begin{array}{l}\text { Mantan Ketua DPD Fraksi } \\
\text { PKS }\end{array}$ \\
\hline 9. & Hadi Mulyadi & $\begin{array}{l}\text { Pembina Garbi Kalimantan } \\
\text { Timur }\end{array}$ & $\begin{array}{l}\text { Wakil Gubernur Kaltim } \\
\text { melalui partai PKS }\end{array}$ \\
\hline
\end{tabular}




\begin{tabular}{|c|c|c|c|}
\hline 10. & Hamy Wahjunianto & Pembina Garbi Jawa Timur & $\begin{array}{l}\text { Ketua DPW PKS Jawa } \\
\text { Timur }\end{array}$ \\
\hline 11. & Ahmad Hasan Bashori & $\begin{array}{l}\text { Ketua Umum Garbi Jawa } \\
\text { Timur }\end{array}$ & $\begin{array}{l}\text { Mantan Ketua Deputi } \\
\text { Pendidikan DPW PKS Jawa } \\
\text { Timur }\end{array}$ \\
\hline 12. & Mudjiono & Pembina Garbi Bali & Ketua DPW PKS Bali \\
\hline 13. & Raihan Iskandar & Pembina Garbi Aceh & Ketua MPW PKS Aceh \\
\hline 14. & Lalu Pahrurrozi & $\begin{array}{l}\text { Ketua Garbi Nusa Tenggara } \\
\text { Barat }\end{array}$ & Politisi PKS \\
\hline 15. & Juanda Sukma & $\begin{array}{l}\text { Pembina Garbi Sumatera } \\
\text { Utara }\end{array}$ & $\begin{array}{l}\text { Kabid Humas DPW PKS } \\
\text { Sumatera Utara }\end{array}$ \\
\hline 16. & Totong Suparman & $\begin{array}{l}\text { Pembina Garbi Sukabumi } \\
\text { Raya }\end{array}$ & $\begin{array}{l}\text { Ketua DPD PKS Kabupaten } \\
\text { Sukabumi }\end{array}$ \\
\hline 17. & Luqman Fanani & Ketua Garbi Mojokerto & $\begin{array}{l}\text { Ketua Majelis Pertimbangan } \\
\text { DPD PKS Mojokerto }\end{array}$ \\
\hline 18. & Riswandi & $\begin{array}{l}\text { Pembina Garbi Kalimantan } \\
\text { Selatan }\end{array}$ & $\begin{array}{l}\text { Ketua MPW DPW PKS } \\
\text { Kalimantan Selatan }\end{array}$ \\
\hline 19. & Wahyudi & $\begin{array}{l}\text { Ketua Garbi Kalimantan } \\
\text { Selatan }\end{array}$ & $\begin{array}{l}\text { Sekertaris Umum DPW PKS } \\
\text { Kalimantan Selatan }\end{array}$ \\
\hline 20. & Budi Waskito & Ketua Garbi Medan & $\begin{array}{l}\text { Ketua Umum DPC PKS } \\
\text { Medan Deli }\end{array}$ \\
\hline 21. & Timbas Tarigan & $\begin{array}{l}\text { Ketua Garbi Sumatera } \\
\text { Utara }\end{array}$ & $\begin{array}{l}\text { Ketua Fraksi PKS DPRD } \\
\text { Sumatera Utara }\end{array}$ \\
\hline 22. & Amril Sudiono & $\begin{array}{l}\text { Ketua Garbi Sumatera } \\
\text { Selatan }\end{array}$ & Politisi PKS \\
\hline 23. & Gunawan Ruslan & $\begin{array}{l}\text { Ketua Garbi Lombok } \\
\text { Timur }\end{array}$ & Politisi PKS \\
\hline 24. & Ahmadi & $\begin{array}{l}\text { Deklarator Garbi Jawa } \\
\text { Tengah }\end{array}$ & $\begin{array}{l}\text { Wakil Ketua DPW Jawa } \\
\text { Tengah }\end{array}$ \\
\hline 25. & Fris Dwi Yulianto & Ketua Garbi Jawa Tengah & $\begin{array}{l}\text { Anggota DPRD Semarang } \\
\text { Fraksi PKS }\end{array}$ \\
\hline
\end{tabular}

Sumber: Diolah oleh penulis

Lebih lanjut Anis Matta mengatakan bahwa ide tersebut sama sekali tidak ada motif berdasarkan kekecewaan. Ide ini sudah lama ditulisnya dalam buku "gelombang ketiga Indonesia" sebuah proses perenungan dan kegelisahan selama menjadi aktivis dakwah hingga memasuki gerbang dunia politik. Dalam buku tersebut menggambarkan narasi Indonesia dan kemudian dikaji kembali menjadikannya sebagai sebuah ide kebangsaan. Gelombang pertama yang mengawali segalanya yang dibubuhkan istilah menjadi Indonesia. Gelombang kedua digambarkan sebagai sebuah masa transisi yang dinamainya sebagai menjadi negara-bangsa modern. Kemudian, Gelombang Ketiga digambarkan dalam keadaan yang baru saja dimulai menjadi sebuah ekuilibrium baru di tengah kehidupan modern ini yang dibawa (Matta, 2014). Dengan ide ini berhasil mengantarkan Garbi sebagai organisasi kemasyarakatan. 


\begin{abstract}
"Kalo dibilang berangkat dari sebuah kekecewaan, tentu tidak. Ide ini sudah ada jauh sebelum adanya konflik di internal, dan itu semua sudah saya mulai bersama temanteman sejak tahun 2008. Jadi tidak mesti semua ide itu lahir dari kekecewaan tapi juga bisa berangkat dari sebuah keresahaan”. (Wawancara penulis, tanggal 14 Juli 2019)
\end{abstract}

Dari pernyataan tersebut, Garbi tidak didasari motif ingin merebut sebuah kekuasaan dalam internal PKS ataupun berangkat dari kekecewaan yang selama ini sering mencuak ke publik. Munculnya Garbi ini sebagai tempat untuk bernaung yang baru agar dapat melanjutkan ide atau narasi yang sudah lama. Sebab di dalam internal PKS tidak mendapatkan ruang utamanya narasi arah baru yang didalamnya mengandung unsur pembaharuan sedangkan kultur didalam PKS itu sendiri kelihatannya satu ruang dan suasana yang tidak dapat tumbuh. Pada dasarnya ide arah baru ini ingin dibuat didalam internal PKS tapi karena tidak mendapatkan ruang akhirnya timbullah semacam konflik, yang dianggap sebagai momentum lahirnya gerakan arah baru Indonesia.

Ide arah baru ini sudah ada jauh sebelum munculnya konflik internal di PKS. Sejak tahun 2010 ada sebuah kondisi yang tidak kondusif di internal PKS yang membuat PKS tidak bisa lincah bergerak menggarap konsituennya, melahirkan ide-ide besar. Ide sebagai partai terbuka justru tidak menemukan terang. Arah baru ingin menggarap segmen masyarakat yang tengah bukan agamais semata itu menimbulkan polemik dan kontroversi yang luar biasa di internal PKS. Daya tolaknya luar biasa adanya pengerdilan orientasi tujuan . Ini secara sistematis terjadi dan puncaknya tahun 2015 setalah sidang majelis syuro di PKS terjadilah reposisi bsar secara nasional. Semua orang yang memiliki ide baru dalam mengembangkan partai itu justru tidak mendapatkan tempat.

\title{
Motif Insentif Solidaritas dan Idealisme
}

Motif insentif solidaritas yakni berkenaan kehidupan sosial baru untuk mendapatkan jaringan yang baru. Menjadikannya sesuatu kekuatan untuk mencapai tujuan bersama dengan menghadirkan rasa simpati, perasaan emosional serta moral yang terbentuk pada hubungan antar individu maupun kelompok. Garbi hadir melalui chapter-chapter yang dibentuk di daerah, mendeklarasikan dirinya pertama kali di Sulsel kemudian melebarkan sayapnya ke daerah-daerah lain. Kehadiran Garbi di Makassar sebagai chapter pertama kali melakukan deklarasi diperkuat dengan badan hukum kemenkumham. Sebagai bentuk upaya legalitas Garbi sebagai organisasi kemasyarakatan.

Dengan membawa ide kebangsaan Garbi membangun soliditas ormasnya melalui semua elemen masyarakat dan menyasar generasi millenial sebagai aktor penggerak dalam ide dan gagasan Garbi yang ingin menjadikan Indonesia sebagai kekuatan kelima dunia. Fase-fase gerakan yang dibangun melalui gerakan pemikiran, gerakan sosial, dan gerakan politik sebagai arah gerakan Garbi kedepannya membangun cita-citanya. 
Gerakan pemikiran dilakukan melalui diskusi-diskusi, sekolah politik melalui ABI university, dan kajian keislamanan yang dilakukan secara rutin. Gerakan sosial dibangun sebagai bentuk kesadaran dan kepedulian terhadap penanganan bencana yang terjadi di Indonesia. Sedangkan gerakan politik sebagai langkah konkret, agar dapat mewujudkannya melalui kekuatan politik yang mengakomodasinya. Gerakan pemikiran disebut sebagai pendahuluan kemudian mengantarkan kedalam panggung politik melalui gerakan politik.

\section{Gambar 1. Tiga Fase Gerakan GARBI}

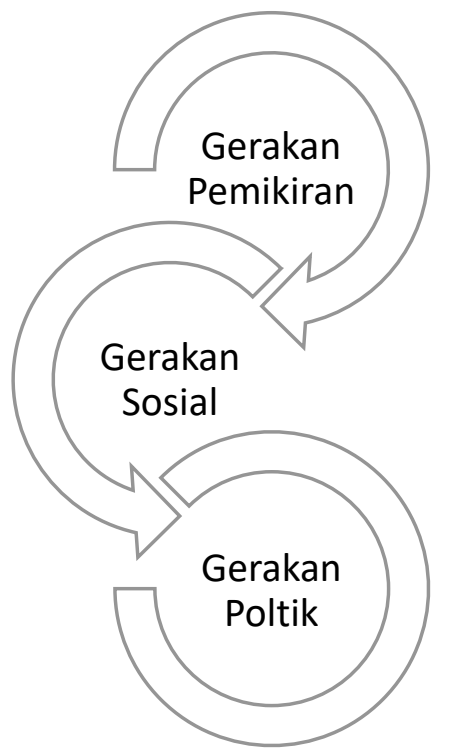

Sumber: Diolah oleh penulis, 2019

Sedangkan motif insentif idealisme ini berkenaan dengan keinginan untuk memperjuangkan sesuatu yang bersifat ideal. Kemampuan dalam manajemen strategis yang meliputi kemampuan dalam menerjamahkan ideologi visi, misi ke dalam program kerja yang kemudian dapat menarik simpatisan sebab dianggap mampu mewakili aspirasi yang identik dengan kepentingan rakyat. Gerakan arah baru Indonesia (Garbi) meyakini besar bisa menjadikan Indonesia sebagai kekuatan kelima dunia melalui tiga aspek fundamental yaitu ekonomi, militer, dan teknologi. Buzan menyatakan terdapat lima dimensi yang saling terkait, yakni: military, political, economic, societal dan environmental. Permasalahan keamanan saat ini lebih kompleks tidak hanya terbatas pada persaingan kekuatan negara besar dunia, namun telah melewati kehidupan berbangsa di seluruh dunia melalui pesatnya globalisasi ditandai dengan perkembangan teknologi dan informasi, integrasi dunia dalam ekonomi dan meningkatnya intensitas hubungan antar negara dalam dunia ekonomi, politik (Buzan, 1991: 433).

Pasca 2008 Garbi melihat terjadi sebuah perubahan mendasar yang secara fundamental dalam skala global terutama krisis ekonomi. Sebab krisis ekonomi dianggap 
runtuhnya sebuah sistem yang ratusan tahun dipakai oleh manusia di dunia yaitu kapitalisme bertemu dengan kecenderungan manusia secara global ini untuk kembali pada agama, sebab realitas kapitalisme dianggap telah membuat nilai-nilai spritual menjadi tergerus. Makanya sekarang muncul sebuah nilai-nilai baru yang terjadi secara global, orang tidak lagi berbicara mengenai ideologi karena menurut mereka ideologiideologi yang ada saat ini kapitalisme sosialisme tidak mampu memberikan jawaba atas perkara mereka. Kalau perubahan global itu terjadi dan bangsa ini tidak siap kita ini akan menjadi negara yang effect to cillidies ada kekuatan global yang bertarung dan negara kita hanya sebagai korban.

Cuman saya mau mengatakan bahwa imajinasi mereka (Huawei) itu 70 tahun. Jadi tahun ini mereka memberikan pesan bahwa tidak ada lagi jarak antara china dan amerika. Secara ekonomi mereka masih kalah nominal tapi daya belinya mereka mengalahkan amerika tinggal secara militer. Kita Indonesia akan hanya menjadi penikmat dari momentum dari dua perang dagang ini, maka kita hanya akan menjadi penonton saja. Maka dari itu kita butuh sebuah cita-cita dan imajinasi kedepan melalui gerakan arah baru Indonesia kita bertekad mewujudkan Indonesia sebagai kekuatan kelima dunia. (Wawancara pada tanggal 14 Juli 2019)

Pada prinsipnya kehadiran Garbi yaitu untuk berjuang mencapai cita-cita pendiri bangsa dengan mengkaloborasikan nilai keislaman, model kesejahteraan, prinsip demokrasi dan spirit demokrasi. Secara garis besar Garbi sebagai organisasi masyarakat membangun ide kebangsaan dengan befokus pada ekonomi, teknologi, dan militer sebagai ide yang sejatinya merupakan sebuah revolusi cerdas (smart revolution) dengan harapan perubahan besar yang dijalankan dengan menekan tombol-tombol perubahan yang besar dalam membawa Indonesia menuju arah baru sebagai kekuatan kelima dunia.

Tabel 3. Keresahaan Garbi

No Bentuk Keresahan
1. Keresahaan melihat negara Indonesia kekurangan narasi besar untuk membawa anak
bangsa pada pikiran dan cita-cita besar yang kontributif untuk negarinya dan umat
manusia
Keresahaan melihat konflik elit membuat energi bangsa ini terkuras habis pada proses
suksesi periodik. Sehingga negara kehilangan fokus terhadap pembangunan jangka
Panjang dan penyiapan generasi baru.

\section{Sumber: Garbi Brief Summary}

Berbagai keresahan tersebut mengantarkan Garbi menjadikannya sebuah organisasi kemasyarakatan yang bergerak dalam tiga fase gerakan utamanya pada gerakan pemikiran yang menjadi landasan awal Garbi. Timbul pertanyaa besar kelahiran Garbi merupakan cikal bakal bakal lahirnya partai politik baru dalam kancah perpolitik di Indonesia, tentunya menimbulkan pertanyaan besar. Hingga penelitian ini 
dilakukanan opini tersebut masih desas-desus, namun dalam hasil wawancara penulis bersama penggagas Garbi Anis Matta, mengatakan:

Gerakan arah baru indoenesia hampir pasti menjadi sebuah gerakan politik. Ide arah baru merupakan ide kebangsaan yang dimana ide ini kita tidak dapat wujudkan kecuali ada kekuatan politik yang mengakomodasinya. Gerakan pemikiran ini disebut sebagai pendahuluan kemudian gerakan sosial merupakan sebuah gerakan yang nantinya langsung dirasakan oleh semua element masyarakat. Tentunya dari itu semua mengantarkannya kedalam panggung politik melalui gerakan politik. (Wawancara pada tanggal 14 Juli 2019)

Lebih lanjut Fahri Hamzah yang merupakan wakil DPR RI periode 2014-2019 yang juga salah satu penggagas Garbi sudah dahulu blak-blakan terhadap media bahwa Garbi sudah akan dipastikan menjadi partai politik, dalam berbagai media Fahri Hamzah memberi bocoran bahwa kedepannya Garbi akan menggelorakan Indonesia melalui arah barunya, sebagai gagasan baru yang akan menghapus gagasan-gagasan lama, tentunya dengan arah baru, Indonesia akan menjadi negara yang ditakuti oleh negara lain dan menjadi kekuatan besar sesuai dengan cita-cita Garbi menjadikan Indonesia sebagai kekuatan kelima dunia.

\section{Struktur Kesempatan Politik Pembentukan Garbi}

Struktur kesempatan politik menjelaskan gerakan sosial terjadi karena disebabkan oleh perubahan dalam struktur politik, yang dilihat sebagai kesempatan. Struktur kesempatan politik ketika akses kepada lembaga-lembaga politik yang mengalami keterbukaan, kemudian keseimbangan politik sedang mengalami caruk-maruk sedang keseimbangan politk baru belum mengalami pembentukan, selain itu kesempatan politik diakibatkan konflik elit politik kemudian dimanfaatkan sebagai kesempatan untuk melakukan perubahan. Kasus konflik dan perpecahan partai yang berlangsung selama era reformasi umumnya terjadi oleh berbagai latar belakang, mulai dari perbedaan pandangan pada visi-misi partai, perpecahan dukungan pencalonan dalam pemilu presiden, tidak terakomodasinya usulan di dalam partai, serta perbedaan pemberian dukungan terhadap calon pimpinan partai di dalam suksesi internal partai (Budiatri et al., 2017).

Garbi semakin progresif dengan terus melalukan deklarasi kepengurusan sejak november 2018. Sementara ini telah memiliki 26 kepengurusan di daerah, data terakhir tebentuk di chapter Jawa Barat setelah sebelumnya terbentuk di DKI Jakarta. Eksistensi Garbi dianggap akan menggeser eksistensi PKS. Garbi dianggap sebagai bentuk perlawanan Anis Matta dan para loyalisnya terhadap DPP PKS. Bahkan pembentukan Garbi dianggap sebagai langkah antisipasi atas situasi paling buruk agar PKS tidak lolos ke senayan pada pemilihan legislatif 2019. Namun pada perolehan suara Pileg 2019 suara PKS justru melonjak naik di banding pada pileg 2014. Berdasarkan rekapitulasi suara PKS berhasil meraup suara 11.493 .663 (8,21\%), Sedangkan pada Pileg 2014, PKS 
meraih 8.480.204 suara atau 6,79\%. Jadi, pada Pileg 2019 suara PKS naik sebesar $3.013 .459(1,42 \%)$.

Tabel 4. Perolehan Suara Partai Tahun 2019

\begin{tabular}{ll|l|l} 
PARTAI POLITIK & 2014 & $2019^{*}$ & SUARA NAIK \\
\hline PKS & 6.79 & 8.62 & 1.83 \\
\hline NASDEM & 6.72 & 8.27 & 1.55 \\
\hline GERINDRA & 11.81 & 12.84 & 1.03 \\
\hline PDIP & 18.95 & 19.97 & 1.02 \\
\hline PKB & 9.04 & 9.27 & 0.23 \\
\hline PKPI & 0.91 & 0.23 & -0.68 \\
\hline PBB & 1.46 & 0.75 & -0.71 \\
\hline PAN & 7.59 & 6.62 & -0.97 \\
\hline PPP & 6.53 & 4.60 & -1.93 \\
\hline GOLKAR & 14.75 & 11.89 & -2.86 \\
\hline DEMOKRAT & 10.9 & 8.03 & -2.87 \\
\hline HANURA & 5.26 & 1.35 & -3.91 \\
\hline PERINDO & & 2.85 & \\
\hline PSI & & 2.07 & \\
\hline PARTAI BERKARYA & & 2.12 & \\
\hline PARTAI GARUDA & & 0.53 & \\
\hline
\end{tabular}

Sumber: Diolah oleh penulis, 2019

Kesempatan politik Garbi semakin progresif ditengah hangatnya pemilu 2019, partisipasi masyarakat terhadap politik dinilai sangat memiliki antusiasme yang tinggi, utamanya dikalangan generasi millenial yang "melek" politik. Pembentukan Garbi ini dirasa tepat dengan mengambil momentum sebelum pileg dan pilpres 2019, Garbi Sulsel pertama kali di deklarasikan pada November 2018 dengan menawarkan ide kebangsaan dan gagasan baru yang lebih segar agar simpatisan massa yang lebih besar.

Bagaimanapun juga kita mesti berangkat pada tujuan kita, berangkat dari kendaraan lama tentunya sudah tidak bisa karena tidak mendapat saluran dan sebagainya. Nah tentunya kita ingin menggunakan sebuah kendaraan baru agar bisa dilihat publik. Bahwasanya ada kekuatan baru yang menawarkan gagasan-gagasan yang lebih segar. Tentunya kita juga melihat partisipasi masyarakat yang sangat antusias dengan poltik, yang lagi melek-meleknya tentang politik, nah kita juga hadir menawarkan gagasan kebangsaan itu". (Wawancara pada tanggal 11 juli 2019).

Kehadiran Garbi ditengah hangatnya pesta demokrasi utamanya menyasar generasi millennial untuk mensosialisaikan ide kebangsaan, meningkatnya generasi millennial yang dinilai mampu menjadi penentu keberhasilan calon baik tingkat daerah maupun nasional. Kominisoner KPU Pramono Ubaid, pemilih dari kalangan umur 17 hingga 34 tahun ini diperkirakan memberi pengaruh besar, yakni sekitar 40-45 persen 
terhadap hasil pemilu 2019. Berdasarkan data KPU jumlahnya mencapai 70-80 juta dari sekitar 193 juta pemilih.

Gambar 2. Presentase Pemilih Millenial

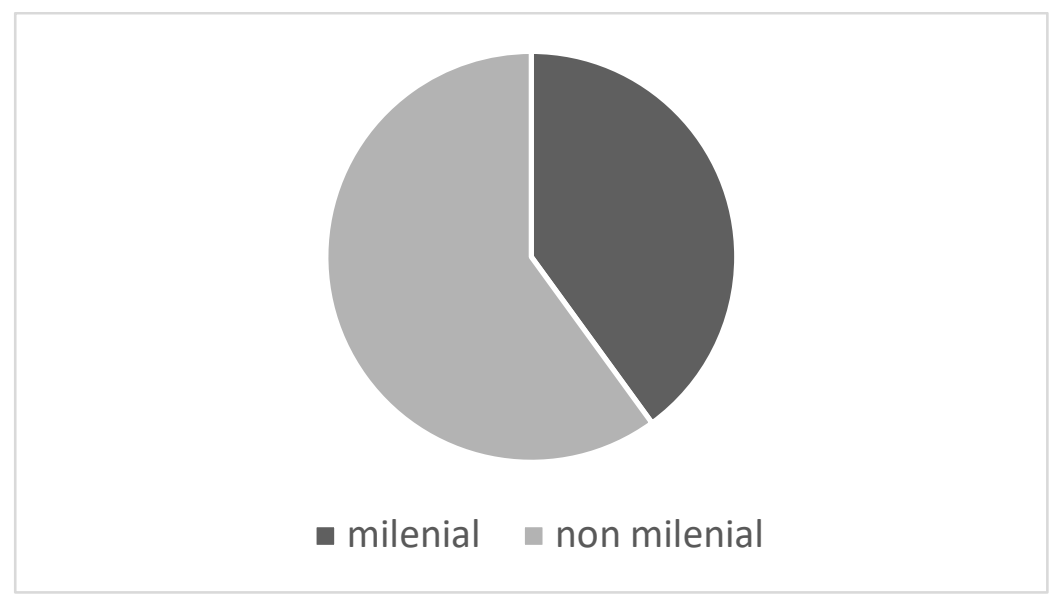

Sumber: Republika.co.id, 2018

Peningkatan suara generasi millennial merupakan upaya baik selain mensosialisasiakan ide kebangsaan juga mengajak langsung generasi millenial untuk ikut langsung berpatisipasi langsung dalam gerakan pemikiran, dengan mengaharikan diskusi kebangsaan, diskusi publik, maupun diskusi mengenai kondisi kenegaraan saat ini ditengah hangatnya pemilu. Pemilu 2019 dinilai sebagai rematch atau tanding ulang antara petahan presiden Joko Widodo dan ketua umum partai gerindra Prabowo Subianto. Dengan adanya dua kubu memungkinkan masyrakat terpolarisasi tinggi, ditambah pemilu tahun 2019 merupakan momentum kedua pasangan calon mengadu gagasan yang kuat untuk menawarkan ide yang segar mengenai indonesia. Garbi cenderung memanfaatkan peluang ini dalam membranding dirinya untuk mampu memberikan warna baru, ide dan gagasan baru sehingga kesempatan ini dianggap sebagai momentum memperkenalkan Garbi.

\section{Struktur Mobilisasi Pembentukan Garbi}

Struktur mobilisasi yak cara suatu kelompok gerakan sosial melebur dalam aksi kolektif, termasuk didalamnya taktik gerakan dan bentuk organisasi sosial. Mobilisasi merupakan kendaraan kolektif baik formal dan informal sebuah organisai, kendaraan ini yang nantinya akan berbaur dalam aksi bersama. Gerakan arah baru Indonesia (Garbi) berkonsentrasi pada jaringan informal yang sifatnya botton up dengan berorientasi pada organisasi kemasyarakatan maupun gerakan sosial.

Secara struktral keberadaan chapter-chapter sudah menyusun struktural yang baik hingga ke tingkat kecamatan, namun secara AD/ART belum rampung secara nasional. berawal dari terbententuknya chapter sulsel merupakan gerbang bagi chapterchapter yang berada diberbagai daerah lain melakukan deklarasi dengan badan hukum yang mengikut melalui chapter sulsel sebagai chapter induk. Gerakan sosial melalui mobilisasi sebuah upaya ketika sistem yang ada tidak mampu menjawab problematika 
dalam berbangsa dan bernegara. Sari (2017) bahwa aksi mobilisasi tentunya tidak hanya menjadi bagian dari orang-orang lama yang dianggap ingin melanjutkan karier politiknya, namun mobilisasi juga menjadi bagian keberadaan individu yang tak dapat dipisahkan dari masyakarakat. Tentunya individu akan berinterkasi dengan lingkungan kesatuan masyarakatnya, baik berawal dari lingkungan masyarakat, lingkungan profesi, lingkungan pekerjaan, keagamaan dan seterusnya. Peranan setiap individu ini membentuk sebuah keresahan yang tidak lagi menjadi keresahannya saja melainkan keresahan sebagai individu yang berbangsa dan negara.

Mobilisasi ini terjadi awalnya itu berangkat dari buku saya "gelombang ketiga Indonesia" yang sudah ada sejak tahun 2013, kemudian saya menindak lanjuti ide itu dengan mengembangkan memberikan dia turunan yang lebih spesifik yaitu ide arah baru Indonesia waktu saya melakukan ceramah di KAMMI. Beberapa bulan kemudian lahirlah GABRI sebagai kendaraan yang membawa ide arah baru Indonesia ini. Jadi saya hanya menyampaikannya idenya 2018, kemudian teman-teman daerah melakukan konsolidasi dan mobilisasi dengan menggerakkan gerakan ini, melalui kajian dan diskusi kebangsaan. (Wawancara pada tanggal 14 Juli 2019)

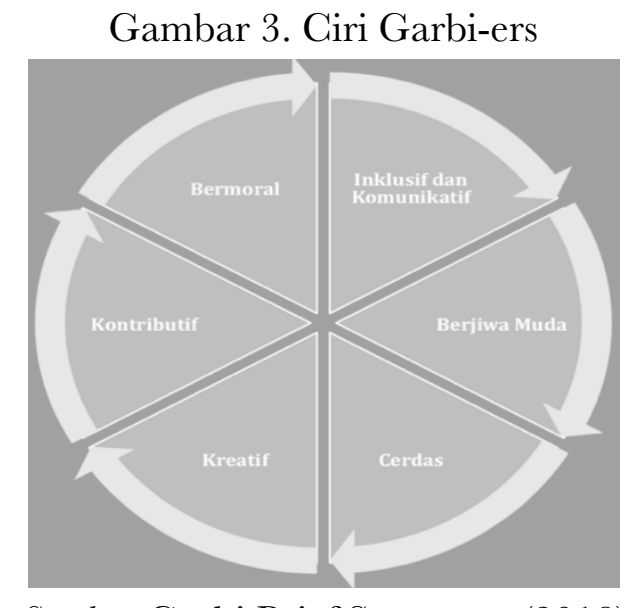

Sumber: Garbi Brief Summary (2018)

Sejak pembentukan chapter diberbagai daerah utamanya melalui gerakan pemikiran, Garbi sering membuka ruang diskusi dengan sasaran anak muda, yang secara tidak langsung juga merupakan sumber pendanaan dalam organisasi masyarakat. Tentunya sebagai penggerak ide kebangsaan Garbi membuka ruang-ruang literasi yang hasil dari kajian tersebut kemudian dicetak agar menjadi saluran pendanaan Garbi. Secara garis besar, pendanaan saat ini melalui medium swadaya oleh masing-masing penggerak, yang dianggap sebagai kerja ikhlas demi membangun Indonesia melalui solusi baru. Selain itu pendanaan Garbi juga hadir melalui dari donatur-donatur yang berkeinginan memberikan sumbangsih melalui open donation pada masing-masing chapter yang ada di berbagai daerah. 


\section{Pembingkaian Aksi Pembentukan Garbi}

Pembingkaian aksi (framing) umumnya dilakukan oleh pelaku maupun aktor yang ingin melakukan penyebaran pandangan darinya kepada orang banyak. Proses pembingkaian ini lebih menekankan pada peranan atau usaha untuk menguasai ide - ide dan identitas baru dalam membentuk suatu gerakan sosial. Framing suatu upaya untuk membelokkan realitas berdasarkan kepentingan tertentu untuk dapat diterima sebagai asumsi kebenaran bagi masyarakat. Dalam perspektif gerakan sosial framing tentu digunakan sebagai upaya untuk menjaring simpati masyarakat yang tujuannya untuk memunculkan gerakan sosial. Oleh karenanya upaya framing tidak dapat dilepaskan dari peran media sebagai alat pemberi pesan. Melalui framing, media massa secara tidak langsung telah mengkonstruksi makna terhadap suatu peristiwa, sehingga persepsi masyarakat terhadap realitas dapat dibentuk sesuai dengan keinginan pembuat framing.

Mensosialisasikan sebuah gerakan utamanya gerakan kemasyarakatan atau yang lebih dikenal dengan organisasi masyarakat tentunya menggunakan segala medium utamanya media massa maupun media sosial. Dalam konteks komunikasi, kampanye merupakan segala kegiatan yang bersifat membujuk. Intinya, di dalam kampanye terjadi serangkaian tindakan komunikasi yang ditujukan untuk membujuk sejumlah besar khalayak. Di sini terlihat bahwa untuk mencapai efek yang diharapkan, penting sekali untuk mengenal siapa khalayak, apa yang dinilami penting dan tidak penting oleh khalayak. Dengan kata lain perlu untuk menggali budaya dari khalayak yang akan dipersuasi (Loisa \& Setyanto, 2016). Garbi sebagai ormas kebangsaan menggunakan pembingkaian aksi (framing) sebagai medium sosialisasi untuk menyampaikan pesannya kepada masyarakat. Melalui framing para aktor gerakan dapat membentuk persepsi masyarakat terhadap ide maupun gagasan tersebut. Media sosial sangat menjadi medium populer dalam mensosialisasikan Garbi utamanya melalui aplikasi Instagram, keselurahan chapter Garbi yang berada diberbagai provinsi maupun kota dapat dengan mudah ditemui di media sosial melalui aplikasi Instagram. Tidak hanya ekspansi framing juga dilakukan melalui facebook, youtube dan website yang dapat diakses secara langsung.

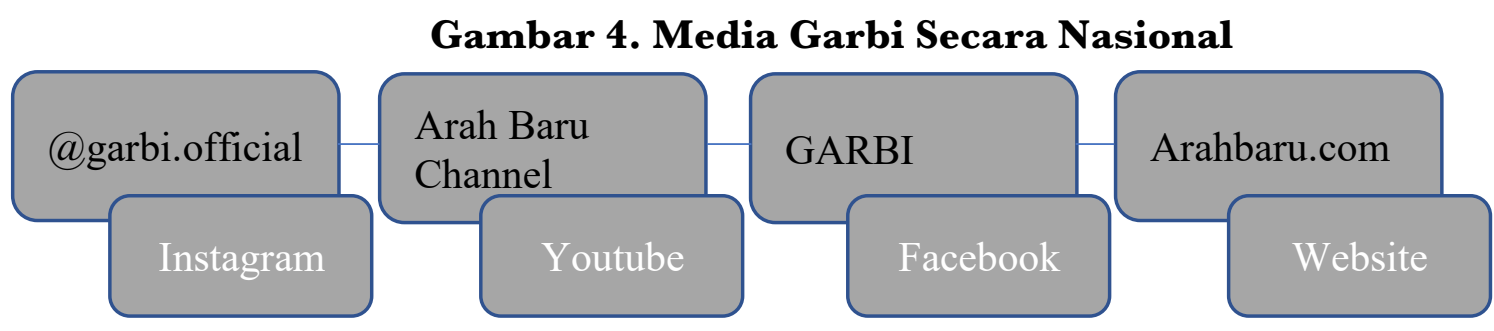

Sumber: Diolah oleh penulis, 2019

Keberadaan media sosial ini tidak hanya menjadi medium Garbi dalam mensosialisasikan ide kebangsaan yang dibawanya, karena basicnya Garbi bergerak dari bawah, maka ranah gerakan pemikiran juga dilakukan dengan mengadakan diskusi 
mingguan, ada MISKAT (Majelis Islam Kebangsaan Moderat), kemudian melalui ABI University sebagai sekolah politik, serta memanfaatkan tokoh politik yang memiliki daya tarik kuat untuk mengumpulkan simpatisan secara massif. Fahri hamzah yang juga merupakan penggagas Garbi dengan blusukan keberbagai daerah melakukan diskusi dalam konten "ngopi bareng Fahri Hamzah" kegiatan ini guna memberikan pengetahuan, dan memperkenalkan Garbi kepada pada masyarakat.

\section{Penutup}

Motif politik kelahiran Garbi berangkat dari sebuah keresahan negara Indonesia kekurangan narasi besar, melihat potensi yang begitu besar utamanya pada generasi baru, disamping itu lemahnya kepemimpinan nasional dalam memobilisasi kekuatan terbaik bangsa sehingga keresahan itu menghimpun gerakan arah baru Indonesia menjadi sebuah organiasi kemasyarakatan dengan menawarkan ide dan gagasan baru, sehingga bertekad mengantarkan Indonesia menjadi negara kekuatan kelima dunia. Selain berangkat dari keresahan melihat kondisi negeri ini, kekecewaan pun tampak terlihat motif dibalik kelahiran dan pembentukan Garbi, terbukti dari banyaknya mantan kader PKS yang terlibat langsung dan berperan aktif di Garbi. Bahkan tak sedikit dari mereka mendapatkan jabatan strategis di Garbi. Hal ini menandakan kekecewaan itu tetap ada meskipun dapat dikelola dengan baik.

Lebih lanjut momentum pemilihan legislatif dan pemilihan presiden 2019 merupakan momentum yang dinilai sangat tepat untuk memperkenalkan Garbi kepada masyarakat, dengan keterbukaan Garbi hadir mendesiminasi ide dalam menggerakkan seluruh aneka ragam potensi anak bangsa, melalui tiga fase gerakan yang dilakukan yakni gerakan pemikiran, gerakan sosial, dan gerakan politik. Meski dalam fase perjalanan Garbi, kabarnya akan bertransformasi menjadi sebuah partai politk. Selain itu, aksi mobilisasi terus dilakukan hingga nantinya ditetapkan struktural secara nasional, dengan itu terus berupaya mensosialisasikan ide dan mengumpulkan simpatisan melalui pembingkaian aksi (framming).

Berdasarkan tiga motif politik tersebut, motif insentif material, motif insentif solidaritas dan motif insentif idealism. Motif solidaritas dianggap yang paling berpengaruh sebab dalam penelitian menunjukkan bahwa ide yang dibawa oleh Anis Matta yang dituangkan dalam buku Gelombang Ketiga Indonesia memiliki dampak yang sangat besar, sehingga bisa menggerakkan aktor-aktor membangun soliditas dan solidaritas dalam membentuk Gerakan Arah Baru Indonesia (Garbi) utamanya aktoraktor yang ada di daerah, sehingga motif insentif solidaritas dianggap penulis sangat berpengaruh dalam tiga motif tersebut pembentukan gerakan arah baru Indonesia secara nasional.

Selanjutnya, berdasarkan tiga teori gerakan sosial yaitu struktur kesempatan politik, sturuktur mobilisasi, dan pembingkaian aksi. Teori yang paling berpengaruh dalam pembentukan gerakan arah baru Indonesia yaitu pembingkaian aksi sebab 
berdasarkan penelitian penulis, pembingkaian aksi sangat menjadi medium yang paling vital dalam mensosialisasikan ide kebangsaan yang dibawa oleh Garbi utamanya gerakan pemikiran, gerakan sosial, dan gerakan politik, yang hampir seluruh rangkain informasi dan referensi mengenai Garbi bisa disampaikan pada masyarakat melalui media elektronik utamanya media sosial, sehingga seluruh lapisan masyarakat utamanya anak muda dapat menjadi bagian penting untuk menjalankan ide maupun gagasan yang dibawa oleh gerakan arah baru Indonesia.

\section{Ucapan Terima Kasih}

Terima kasih kepada semua pihak yang turut berkontribusi pada pendalaman diskusi selama proses penyusunan artikel.

\section{Pendanaan}

Penulis tidak menerima bantuan pembiayaan untuk penelitian, kepenulisan (authorship), dan publikasi dari pihak manapun.

\section{Daftar Pustaka}

Akmar, Z. (2019). Konflik Internal Partai Keadilan Sejahtera (PKS) Tahun 2016: Studi KAsus Konflik Fahri Hamzah dengan Pinpinan Dewan Pengurus Pusat (DPP) PKS. Politika: Jurnal Ilmu Politik, 10(1), 1-27.

Aminuddin, M. F., \& Ramadlan, M. F. S. (2015). Match-All Party: Pragmatisme Politik dan Munculnya Spesies Baru Partai Politik di Indonesia Pasca Pemilu 2009. Jurnal Politik, 1(1), 39-74.

Beck, P. A., \& J.Sorauf, F. (1992). Party Politics in America. USA: Harper Collins Publisher.

Budiatri, A. P., Haris, S., Romli, L., Nuryanti, S., Nurhasim, M., Darmawan, D., \& Hanafi, R. I. (2017). Faksi Dan Konflik Internal Partai-Partai Politik Di Indonesia Era Reformasi. Jurnal Penelitian Politik, 14(2), 261-275.

Buzan, B. (1991). People, States and Fear: An Agenda for International. Security Studies in the Post-Cold War Era, 2nd Ed.(London: Harvester Wheatsheaf, 1991).

Gunther, R., \& Diamond, L. (2003). Species of Political Parties: A New Typology. Party Politics, 9(2), 167-199.

Hasan, N. (2006). Book Review: Islam Politik, Teori Gerakan Sosial, dan Pencarian Model Pengkajian Islam Baru Lintas-Disiplin. Al-famiah: Fournal of Islamic Studies, 44(1), 241-250.

Huntington, S. P., \& Simamora, S. (1983). Tertib Politik di dalam Masyarakat yang sedang Berubah. GV. Rajawali.

Kartono, K. (2018). Pemimpin dan Kepemimpinan. Rajawali Pers.

Loisa, R., \& Setyanto, Y. (2016). Penyingkapan Diri Melalui Internet Di Kalangan Remaja (Studi Komunikasi Antar Pribadi). Jurnal Komunikasi, 6(3), 31-43.

Matta, A. (2014). Gelombang Ketiga Indonesia. Jakarta: The Future Institute.

Muhtadi, B. (2013). Dilema PKS. Kepustakaan Populer Gramedia.

Munandar, A. (2011). Antara Jemaah dan Partai Politik. 
Noor, F. (2015). Perpecahan E Solidaritas Partai Islam di Indonesia: Kasus PKB dan PKS di Dekade Awal Reformasi. LIPI Press.

Nurdin, M. A., Saputra, A. T. D., \& Prayitno, A. (2019). Prahara Partai Islam: Komparasi Konflik Internal PPP dan PKS. Yayasan Pustaka Obor Indonesia.

Rivai, Mu. (2016). PKS Di Masa Sulit: Studi Atas Eksistensi Dan Stabilitas PKS Di Tengah Momentum Kritis Yang Mengancam Masa Depan Partai Periode 1998-2014 MUHAMMAD RIVAI, 1-33., 1-33.

Romli, L. (2018). Pilkada Langsung, Calon Tunggal, dan Masa Depan Demokrasi Lokal. Furnal Penelitian Politik, 15(2), 143-160.

Sari, D. K. (2017). Strategi Mobilisasi Gerakan Masyarakat dalam Penutupan Industri Pengelolaan Limbah B3 di Desa Lakardowo Kabupaten Mojokerto. Jurnal Politik Indonesia, 2(1), 127-134.

Situmorang, A. W. (2007). Gerakan Sosial: Studi Kasus Beberapa Perlawanan. Pustaka Pelajar.

Surbakti, R. (1999). Formal political institutions. Indonesia: The Challenge of Change. Singapore: ISEAS.

Terry, G. R., \& Smith, J. (1990). Prinsip-Prinsip Manajemen. Bumi Aksara.

Tomsa, D. (2012). What Type of Party? Southeast Asian Parties Between Clientelism and Electoralism. In Party Politics in Southeast Asia (pp. 38-57). Routledge.

Wahyudi. (2011). Manajemen Konflik dalam Organisasi, (Cetakan Keempat). Bandung: Alfabeta.

Walgito, B. (2010). Pengantar Psikologi Umum, Edisi Revisi. Yogyakarta: CV. Andi Offset.

\section{Daftar Informan}

M. Anis Matta, Penggagas dan Inisiator Garbi (wawancara di Jakarta pada 14 Juli 2019).

Feri A. Ibrahim, Ketua Umum Garbi DKI Jakarta (wawancara di Jakarta pada 11 Juli 2019).

Luthfi Al fikri, Ketua Umum Garbi DI. Yoygakarta (wawancara di Yogyakarta, pada 08 Agustus 2019),

Muh. Taslim Tamang, Ketua Harian Garbi Sulsel (Wawancara di Makassar, pada 30 Juni 2019)

Irwan S.T., Sekertaris Umum Garbi Sulsel (wawancara di Makassar, pada 19 Juni 2019)

\section{Tentang Penulis}

Arfan Ashari Saputra adalah mahasiswa Magister Ilmu Pemerintahan, Universitas Muhammadiyah Yogyakarta.

Ridho Al-Hamdi adalah dosen di Program Studi Ilmu Pemerintahan, Universitas Muhammadiyah Yogyakarta. Penulis memiliki area kajian seputar partai politik, pemilu, demokrasi, Islam dan politik. 